\title{
PHYLOGEOGRAPHY OF THE SCALED QUAIL IN THE AMERICAN SOUTHWEST
}

\author{
Damon Williford ${ }^{1,3}$, Randy W. DeYoung ${ }^{1}$, Rodney L. Honeycutt ${ }^{2}$, \\ Leonard A. Brennan ${ }^{1}$, and Fidel Hernández ${ }^{1}$
}

\begin{abstract}
We used sequences from the mitochondrial control region to examine the phylogeography and historical demography of the Scaled Quail and to determine whether the geographic distributions of mtDNA genealogy were concordant with the distribution of the subspecies. Overall, the Scaled Quail exhibited lower haplotype and nucleotide diversity than other quail species. The highest levels of haplotype diversity were found in 3 Texas counties: Dimmit, La Salle, and Hudspeth. The Scaled Quail exhibited no phylogeographic structure among its 16 haplotypes, and the patterns of genetic variation were not congruent with potential geographic barriers or current subspecies taxonomy. The geographic distribution of haplotypes and partitioning of molecular variation suggested slight genetic differentiation between the chestnut-bellied subspecies of Scaled Quail and the 3 western subspecies. The low levels of genetic diversity and the evidence of demographic expansion suggest that the Scaled Quail has undergone population and range expansion from a Pleistocene refugium. The greater genetic diversity within the Chestnut-bellied Quail may indicate the geographic location of the refugium.
\end{abstract}

Resumen.-En este estudio se utilizaron secuencias de mitocondrias de control regional para examinar la filogeografía y la demografía histórica de la codorniz escamosa para determinar si las distribuciones geográficas de la genealogía ADN mitocondrial eran concordantes con la distribución de las subespecies. En general, la codorniz escamosa mostró menores haplotipos y diversidad de nucleótidos que otras especies de codornices. Los niveles más altos de diversidad de haplotipos se encontraron en tres condados de Texas: Dimmit, La Salle, y Hudspeth. La codorniz escamosa no mostró estructura filo-geográfica entre sus 16 haplotipos y los patrones de variación genética no fueron congruentes con las posibles barreras geográficas o con la taxonomía de subespecies actuales. La distribución geográfica de los haplotipos y la partición de la variación molecular sugiere una ligera diferenciación genética entre las subespecies de codorniz escamosa de vientre castaño y las 3 subespecies occidentales. Los bajos niveles de diversidad genética y la evidencia de la expansión demográfica sugieren que la codorniz escamosa ha experimentado una expansión tanto de su población como de su rango que provienen de un refugio del Pleistoceno. La mayor diversidad genética en la codorniz escamosa de vientre castaño posiblemente indique que la distribución de esta subespecie sea la ubicación geográfica del refugio.

The Scaled Quail (Callipepla squamata) is a small gallinaceous bird (Odontophoridae) distributed across arid grasslands, brushlands, and desert scrub of northwestern Mexico and the southwestern United States (Fig. 1). Despite the species' restricted distribution, 4 subspecies have been described. Callipepla s. pallida has the widest distribution and occurs throughout most of the Chihuahuan Desert from southeastern Arizona to western Texas and northern Mexico (Sonora and Chihuahua). Callipepla s. castanogastris occurs in the Tamaulipan Brushlands of southern Texas, Nuevo Leon, and Tamaulipas; C. s. squamata occurs throughout the Mexican Central Plateau from southern Sonora to the Valley of Mexico; and C. s. hargravei comprises populations in the
Southern High Plains and Colorado Plateau (Dabbert et al. 2009). Callipepla s. hargravei, C. s. pallida, and C. s. squamata are designated on the basis of geography and subtle differences in the tone of bluish gray plumage, whereas C. s. castanogastris is distinguished from the other 3 subspecies by its chestnut or copper-colored belly.

Callipepla was formerly considered a monotypic genus. However, many ornithologists suggested a close relationship between the Scaled Quail and the 3 species formerly placed in the genus Lophortyx: Elegant Quail (C. douglasii), California Quail (C. californica), and Gambel's Quail (C. gambelii) (Holman 1961, Mayr and Short 1970, Hubbard 1973). Molecular studies based on allozymes (Gutíerrez et al. 1983) and

\footnotetext{
${ }^{1}$ Caesar Kleberg Wildlife Research Institute, Texas A\&M University Kingsville, Kingsville, TX 78363.

${ }^{2}$ Natural Science Division, Pepperdine University, Malibu, CA 90263.

32E-mail: damon.williford@tamuk.edu
} 


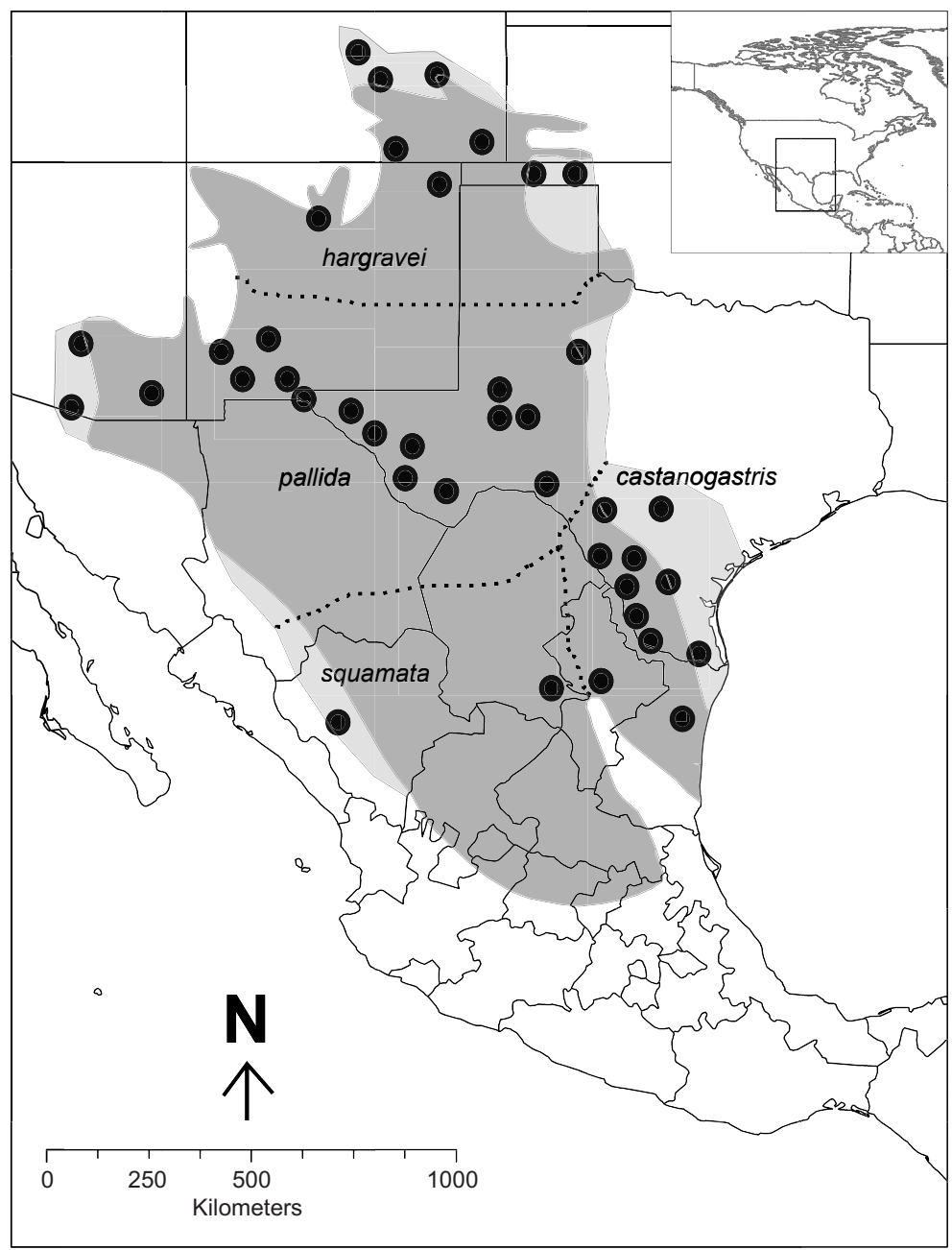

Fig. 1. Historical (light gray) and contemporary (dark gray) geographic ranges of the Scaled Quail (Callipepla squamata) and its subspecies. Contemporary distribution is based on Ridgely et al. (2007), and historic distribution is based on data from Texas Game, Fish and Oyster Commission (1945), Ridgway and Friedmann (1946), Schemnitz (1959), Rea (1973), and Dabbert et al. (2009). Black dots represent localities from which contemporary specimens (hunter-harvested or trapped birds) were acquired or collection localities of museum specimens.

mitochondrial DNA (mtDNA) sequences (Zink and Blackwell 1998) confirmed the close relationship among these 4 species. Hubbard (1973) proposed that the Scaled Quail, Elegant Quail, and a pre-californica-gambelii lineage split from a common ancestor during the Illinoian Stage of the Pleistocene (300-130 thousand years ago) in response to climatic and ecological changes. Estimates of divergence times based on molecular data indicate that Callipepla species originated during the Late Pliocene and Early Pleistocene, 2.8-1.0 million years ago (Gutíerrez et al. 1983, Zink and Blackwell 1998).
The climate of southwestern North America changed dramatically throughout the Late Quaternary in response to Milankovitch cycles of cool 100,000-year glacial periods interrupted by warmer 10,000-year interglacials (Graham 2011). Arid- and desert-adapted taxa of the American Southwest typically exhibit strong phylogeographic structure due to isolation in multiple refugia during cooler, wetter glacials. However, many species also show evidence of post-Pleistocene expansion in some parts of their respective ranges (Zink et al. 2001, Zink 2002, Riddle and Hafner 2006). If the Scaled 
TABLE 1. Collection localities of hunter-harvested and trapped specimens of Scaled Quail (Callipepla squamata) from the United States used in this study.

\begin{tabular}{llcc}
\hline State & County & $\begin{array}{c}\text { Number of } \\
\text { samples }\end{array}$ & Year collected \\
\hline Arizona & Pima & 7 & 1999 \\
Colorado & Lincoln & 13 & 2009 \\
Texas & Brewster & 17 & $2008-2009$ \\
& Culberson & 13 & $2008-2009$ \\
& Dimmit & 26 & $2008-2009$ \\
& Fisher & 10 & $2008-2009$ \\
& Hudspeth & 13 & $2008-2009$ \\
& Jeff Davis & 12 & $2009-2010$ \\
& La Salle & 7 & 2011 \\
& Midland & 8 & $2008-2009$ \\
& Reagan & 12 & $2008-2009$ \\
& Upton & 14 & $2008-2009$ \\
New Mexico & Dona Ana & 15 & $2009-2010$ \\
& Luna & 15 & $2009-2010$ \\
& Sierra & 3 & $2009-2010$ \\
Oklahoma & Beaver & 1 & 2010 \\
& Texas & 4 & 2010 \\
\hline
\end{tabular}

Quail was isolated in multiple refugia, the species should exhibit strong phylogeographic structure. To the contrary, if the Scaled Quail was isolated in a single refugium, it should exhibit little or no phylogeographic structure. We used sequences from the mitochondrial control region to examine the phylogeography and historical demography of the Scaled Quail and to determine whether the geographic distributions of mtDNA genealogy were concordant with the distributions of the 4 subspecies.

\section{METHODS}

\section{Sample Collection and Laboratory Methods}

We obtained 182 contemporary samples of Scaled Quail from individuals that were either harvested or trapped in Texas, New Mexico, Arizona, and Colorado during 2008-2010 (Table 1). Extracted DNA was also obtained from 8 Scaled Quail trapped in 2004 at the Buenos Aires National Wildlife Refuge, Arizona. We supplemented the contemporary samples with tissues obtained from museum specimens of Scaled Quail, including toepads or feathers (Table 2). Toepad samples consisted of small (3 $\times 1 \times 1 \mathrm{~mm}$ ) pieces of skin cut from the ventral side of the foot via a sterile razor or scalpel blade (changed for each specimen; Mundy et al. 1997). Each skin or feather sample was placed in either a sterile $2.0-\mathrm{mL}$ tube with a screw cap or a small plastic Ziploc ${ }^{\circledR}$ bag, and all were stored at room temperature. We extracted genomic DNA by using the DNeasy ${ }^{\circledR}$ Blood \& Tissue Kit and tissue protocol (Qiagen, Valencia, CA). Because contamination represents one of the most serious problems during work with DNA extracted from museum specimens (Mulligan 2005), we used an anticontamination protocol developed from the recommendations of Hummel (2003), Pääbo et al. (2004), and Mulligan (2005); specific details may be found in Williford (2013).

The mitochondrial control region displays high levels of variability, making it a useful genetic marker for studies of recently diverged populations (Vigilant et al. 1991, Wenink et al. 1994). Primers L16755 (5' TAC GGC TTG AAA AGC CAT TG 3') (Nedbal et al. 1997) and OSU7713 (5' CCT GAC CGA GGA ACC AGA GGC GC 3') (Van Den Bussche et al. 2003) were used to amplify $\sim 500$ base pairs (bp) of the highly variable $5^{\prime}$ region of the control region from contemporary Scaled Quail samples. We designed a pair of internal primers, SQCR026-F (5' CTC AAC TAC GGG AAC AGC AT 3') and SQCR301-R (5' GGT GTC TTG TCT GTT GTG TAG G $3^{\prime}$ ) for use in museum specimens, and these primers amplified a $\sim 300 \mathrm{bp}$ fragment from the most variable portion of the fragment produced by the L16755 and OSU7713 primer pair.

Polymerase chain reactions were conducted in $25-\mu \mathrm{L}$ volumes that contained $1.5-3.0 \mu \mathrm{L}$ DNA extract, $12.5 \mu \mathrm{L}$ AmpliTaq ${ }^{\circledR}$ Gold PCR Master Mix (Applied Biosystems, Foster City, CA), 10 pmol of each primer, $1.0 \mu \mathrm{L}$ bovine serum albumin $\left(2 \mathrm{mg} \cdot \mathrm{mL}^{-1}\right)$, and sufficient double-deionized water to reach the final volume. Amplification was performed using an ABI 2720 thermal cycler (Applied Biosystems) with the following protocol: initial denaturation at $94.0{ }^{\circ} \mathrm{C}$ for $10.0 \mathrm{~min}, 35$ cycles of denaturation at $94.0{ }^{\circ} \mathrm{C}$ for $50.0 \mathrm{~s}$, annealing $61{ }^{\circ} \mathrm{C}$ for $1.0 \mathrm{~min}$, extension at $72.0{ }^{\circ} \mathrm{C}$ for 2.0 min, and a final extension of $72.0^{\circ} \mathrm{C}$ for 30.0 min. All PCR products were electrophoresed on a $1 \%$ agarose gel that contained ethidium bromide and were viewed under UV light to verify successful amplification. Amplification products from successful reactions were purified by an enzymatic method (ExoSAP-IT ${ }^{\mathrm{TM}}$, USB Corporation, Wilmington, MD), and sequenced using the ABI BigDye Terminator v1.1 Cycle Sequencing Kit. Dye terminators were removed with the DyeEx 2.0 Spin Kit (Qiagen). Sequence reaction products were then loaded 
Table 2. Museum specimens of Scaled Quail (Callipepla squamata) from Mexico and the United States used in this study. Specimens were obtained from the American Museum of Natural History (AMNH), the Texas Cooperative Wildlife Collection (TCWC), and the University of Colorado Museum (UCM).

\begin{tabular}{|c|c|c|}
\hline Institution-catalog no. & Locality & Year collected \\
\hline AMNH-343908 & Saltillo, Coahuila, Mexico & 1946 \\
\hline AMNH-353956 & Chiricahua Mountains, Cochise County, Arizona, USA & 1991 \\
\hline AMNH-353962 & Santa Rita Mountains, Pinal County, Arizona, USA & 1907 \\
\hline AMNH-353971 & Duval County, Texas, USA ${ }^{\mathrm{a}}$ & 1912 \\
\hline AMNH-472432 & Silver City, Grant County, New Mexico, USA & 1884 \\
\hline AMNH-472434 & San Antonio, Bexar County, Texas, USA & 1889 \\
\hline AMNH-67977 & El Paso, El Paso County, Texas, USA & 1891 \\
\hline AMNH-70058 & Santa Fe, Santa Fe County, Texas, USA & 1893 \\
\hline AMNH-751324 & Benson, Cochise County, Texas, USA & 1907 \\
\hline AMNH-751326 & San Fernando, Tamaulipas, Mexico & 1909 \\
\hline AMNH-80260 & Marfa, Presidio County, Texas, USA & 1887 \\
\hline AMNH-80261 & Chinati Mountains, Presidio County, Texas, USA & 1887 \\
\hline AMNH-80283 & Nuevo Leon, Mexico, Mexico ${ }^{\mathrm{b}}$ & 1889 \\
\hline AMNH-80286 & Nuevo Leon, Mexico ${ }^{\mathrm{b}}$ & 1889 \\
\hline AMNH-80295 & Rio Grande City, Starr County, Texas, USA & 1886 \\
\hline AMNH-80333 & Rio Grande City, Starr County, Texas, USA & 1880 \\
\hline AMNH-80369 & Laredo, Webb County, Texas, USA & 1895 \\
\hline AMNH-826440 & Grenville, Union County, New Mexico, USA & 1989 \\
\hline AMNH-91978 & Rancho Baillon, Guanacevi, Durango, Mexico & 1903 \\
\hline AMNH-91981 & Rancho Baillon, Guanacevi, Durango, Mexico & 1903 \\
\hline AMNH-91982 & Rancho Baillon, Guanacevi, Durango, Mexico & 1903 \\
\hline AMNH-91983 & Rancho Baillon, Guanacevi, Durango, Mexico & 1903 \\
\hline AMNH-91984 & Rancho Baillon, Guanacevi, Durango, Mexico & 1903 \\
\hline TCWC-10562 & Falcon Dam, Zapata County, Texas, USA & 1978 \\
\hline TCWC-10934 & Uvalde County, Texas, USA ${ }^{\mathrm{a}}$ & 1977 \\
\hline TCWC-10935 & Uvalde County, Texas, USA ${ }^{\mathrm{a}}$ & 1977 \\
\hline TCWC-11577 & Pandale Crossing, Val Verde County, Texas, USA & 1986 \\
\hline TCWC-11855 & San Benito, Cameron County, Texas, USA & 1939 \\
\hline TCWC-12982 & Marathon, Brewster County, Texas, USA & 1992 \\
\hline TCWC-2003 & Encinal, La Salle County, Texas, USA & 1939 \\
\hline TCWC-2004 & Encinal, La Salle County, Texas, USA & 1939 \\
\hline TCWC-4385 & Springfield, Baca County, Colorado, USA & 1948 \\
\hline TCWC-5184 & Artesia Wells, La Salle County, Texas, USA & 1951 \\
\hline UCM-7979 & Hoehne, Las Animas County, Colorado, USA & 1908 \\
\hline UCM-7981 & Buffalo Creek, Jefferson County, Colorado, USA & 1905 \\
\hline UCM-7983 & Colorado Springs, El Paso County, Colorado, USA & 1908 \\
\hline UCM-7984 & Colorado Springs, El Paso County, Colorado, USA & 1908 \\
\hline
\end{tabular}

aSpecimen tag provided only county-level collection data.

bSpecimen tag provided only state-level collection data.

on an ABI Prism 3130 Genetic Analyzer (Applied Biosystems) for separation and detection.

\section{DNA Analysis}

Mitochondrial DNA sequences were edited in the computer program Sequencher 4.6 (Gene Codes, Ann Arbor, MI) and aligned using the program ClustalX (Larkin et al. 2007). Preliminary analyses showed that the longer sequences from contemporary samples and the data set from museum specimens all exhibited similar genetic structure and diversity. Therefore, we used the combined set of shorter control region sequences from contemporary and museum specimens for all subsequent phylogeographic and demographic analyses.
We pooled samples by county (USA) and municipality (Mexico) and treated these as populations. Then we grouped the populations by the range of individual subspecies. We used DnaSP version 5.10.01 (Librado and Rozas 2009) to compute the number of haplotypes $(h)$, haplotype diversity $(H d)$, and nucleotide diversity $(\pi)$ (Nei 1987) for each subspecies and each county and municipality. We also computed the haplotype and nucleotide diversity for historical samples (museum specimens collected 1880-1951, $n=30)$ and recent samples (museum specimens and hunterharvested or trapped birds collected between 1977-2010, $n=197)$. We examined relationships among haplotypes by constructing a 
minimum spanning tree in Arlequin version 3.5 (Excoffier and Lischer 2010). The computer program HapStar version 0.6 (Teacher and Griffiths 2011) was used to draw the minimum spanning tree; the tree was further altered in the program Inkscape version 0.48 (Inkscape, http://www.inkscape.org).

We used analysis of molecular variance (AMOVA) as implemented in Arlequin to determine how genetic variation was apportioned among subspecies (Excoffier et al. 1992). We evaluated 5 different arrangements. First, we performed an AMOVA with Scaled Quail populations arranged into 4 groups corresponding to the 4 subspecies. Additional AMOVAs involved arrangements of populations in which we tested each subspecies against a group containing the other 3 subspecies.

Historical events, such as demographic expansion or relative stability, produce distinctive patterns of DNA polymorphisms (Rogers and Harpending 1992). We evaluated the demographic history of the Scaled Quail by computing the observed pairwise nucleotide differences or mismatch distributions. A unimodal observed mismatch distribution is an indication of sudden demographic expansion, whereas bimodal or multimodal mismatch distributions imply demographic equilibrium or decline. We used DnaSP to compute the expected mismatch distribution under a model of constant population size (Watterson 1975, Slatkin and Hudson 1991, Rogers and Harpending 1992) and the observed mismatch distribution of the Scaled Quail. We examined the fit of the observed mismatch distribution to the expected mismatch distribution by using mean absolute error (MAE-Rogers et al. 1996) and the raggedness index $(r$ - Harpending 1994).

We performed several neutrality tests to further assess the demographic history of the Scaled Quail, including Tajima's D (Tajima 1989), Fu and Li's $D^{*}$ and $F^{*}$ (Fu and Li 1993), and Fu's $F_{\mathrm{S}}$ (Fu 1997). Negative values of Tajima's $D, \mathrm{Fu}$ and $\mathrm{Li}$ 's $D^{*}$ and $F^{*}$, and Fu's $F_{\mathrm{S}}$ indicate demographic expansion, whereas positive values may result from demographic contractions, bottlenecks, or population subdivision (Simonsen et al. 1995, Fay and Wu 1999, Depaulis et al. 2003, Ramírez-Soriano et al. 2008). We tested the null hypothesis of selective neutrality by constructing confidence intervals of $95 \%$ for raggedness, Tajima's $D, \mathrm{Fu}$ and Li's $D^{*}$ and $F^{*}$, and Fu's $F_{S}$. Demographic expansion was supported when selective neutrality was rejected by significant small values of raggedness $(P<0.05)$ and significant negative values of Tajima's $D(P<0.05), \mathrm{Fu}$ and Li's $D^{*}(P<0.05)$ and $F^{*}(P<0.05)$, and Fu's $F_{S}\left(P<0.02 ;\right.$ Fu's $F_{S}$ is considered significant only if $P<0.02$ since the $5 \%$ significance level of $F_{S}$ corresponds to the lower second percentile of the empirical distribution; Fu 1997). All neutrality tests were performed in DnaSP, and confidence intervals were obtained with 1000 coalescent simulations in DNASP's coalescent simulator.

\section{RESULTS}

We sequenced $409 \mathrm{bp}$ of the mitochondrial control region from 190 contemporary specimens and 267 bp from 37 of 80 museum specimens of Scaled Quail. All sequences of haplotypes were submitted to GenBank as accession numbers KC495544-KC495559. We observed no contamination in any of the extraction or PCR negative controls. Fourteen control region haplotypes occurred in the contemporary samples. Two singleton haplotypes (one found in Upton County, TX, and the other in Jeff Davis County, TX) were collapsed into haplotype A (the most common haplotype) when the sequences were truncated to $267 \mathrm{bp}$ to align with sequences from museum specimens. Four additional haplotypes occurred in the museum specimens.

Overall, the Scaled Quail exhibited low levels of haplotype and nucleotide diversity $(H d$ $=0.39, \pi=0.002)$. Most populations and the subspecies ranges of C. s. pallida, C. s. hargravei, and C. s. squamata displayed low values of $H d(0.08-0.333)$ and $\pi(\leq 0.001)$. Callipepla s. castanogastris exhibited higher levels of genetic diversity $(H d=0.776, \pi=0.005$; Table 3). Three localities in Texas (Dimmit, La Salle, and Hudspeth counties) exhibited diversity values similar to that of C. s. castanogastris (Hd $\geq 0.664, \pi \geq 0.003)$. Dimmit County, Texas, had the greatest number of haplotypes; however, 27 hunter-harvested samples were collected from this county - a larger sample size than from any other locality.

The minimum spanning tree (Fig. 2) of the Scaled Quail formed a star-like arrangement, where most haplotypes were connected to their nearest neighbors by a single base substitution. 
TABLE 3. Mitochondrial control region (267 bp) genetic diversity indices of the Scaled Quail (Callipepla squamata), its subspecies, and sampled populations. Shown are sample size $(n)$, number of haplotypes $(h)$, haplotype diversity $(H d$, with SD), and nucleotide diversity ( $\pi$, with SD).

\begin{tabular}{|c|c|c|c|c|}
\hline Subspecies and localities & $n$ & $h$ & $H d(\mathrm{SD})$ & $\pi(\mathrm{SD})$ \\
\hline All sequences & 227 & 16 & $0.388(0.041)$ & $0.0020(0.0003)$ \\
\hline C. s. castanogastris & 49 & 10 & $0.776(0.049)$ & $0.0049(0.0006)$ \\
\hline Nuevo Leon ${ }^{\mathrm{a}}$ & 2 & 2 & $1.000(0.500)$ & $0.0074(0.0038)$ \\
\hline San Fernando, Tamaulipas & 1 & 1 & & \\
\hline Bexar County, Texas & 1 & 1 & & \\
\hline Cameron County, Texas & 1 & 1 & & \\
\hline Dimmit County, Texas & 27 & 8 & $0.795(0.061)$ & $0.0050(0.0007)$ \\
\hline Duval County, Texas & 1 & 1 & & \\
\hline La Salle County, Texas & 10 & 4 & $0.711(0.117)$ & $0.0049(0.0014)$ \\
\hline Starr County, Texas & 2 & 2 & $1.000(0.050)$ & $0.0038(0.0019)$ \\
\hline Uvalde County, Texas & 2 & 1 & & \\
\hline Webb County, Texas & 1 & 1 & & \\
\hline Zapata County, Texas & 1 & 1 & & \\
\hline C. s. squamata & 6 & 2 & $0.333(0.215)$ & $0.0013(0.0008)$ \\
\hline Saltillo, Coahuila & 1 & 1 & & \\
\hline Guanacevi, Durango & 5 & 2 & $0.400(0.237)$ & $0.0015(0.0009)$ \\
\hline C. s. hargravei & 24 & 2 & $0.083(0.075)$ & $0.0003(0.0003)$ \\
\hline Baca County, Colorado & 1 & 1 & & \\
\hline El Paso County, Colorado & 2 & 1 & & \\
\hline Jefferson County, Colorado & 1 & 1 & & \\
\hline Las Animas County, Colorado & 1 & 1 & & \\
\hline Lincoln County, Colorado & 13 & 2 & $0.154(0.126)$ & $0.0006(0.0005)$ \\
\hline Santa Fe County, New Mexico & 1 & 1 & & \\
\hline Union County, New Mexico & 1 & 1 & & \\
\hline Beaver County, Oklahoma & 1 & 1 & & \\
\hline Texas County, Oklahoma & 4 & 1 & & \\
\hline C. s. pallida & 148 & 11 & $0.250(0.047)$ & $0.0012(0.0003)$ \\
\hline Cochise County, Arizona & 1 & 1 & & \\
\hline Pima County, Arizona & 8 & 2 & $0.250(0.180)$ & $0.0009(0.0007)$ \\
\hline Pinal County, Arizona & 1 & 1 & & \\
\hline Dona Ana County, New Mexico & 15 & 3 & $0.257(0.142)$ & $0.0010(0.0006)$ \\
\hline Grant County, New Mexico & 1 & 1 & & \\
\hline Luna County, New Mexico & 15 & 4 & $0.371(0.153)$ & $0.0015(0.0007)$ \\
\hline Sierra County, New Mexico & 3 & 1 & & \\
\hline Brewster County, Texas & 18 & 2 & $0.111(0.096)$ & $0.0004(0.0004)$ \\
\hline Culberson County, Texas & 12 & 1 & & \\
\hline El Paso County, Texas & 1 & 1 & & \\
\hline Fisher County, Texas & 9 & 2 & $0.389(0.164)$ & $0.0016(0.0006)$ \\
\hline Hudspeth County, Texas & 13 & 6 & $0.641(0.150)$ & $0.0035(0.0011)$ \\
\hline Jeff Davis County, Texas & 12 & 2 & $0.167(0.134)$ & $0.0006(0.0005)$ \\
\hline Midland County, Texas & 8 & 1 & & \\
\hline Presidio County, Texas & 2 & 1 & & \\
\hline Reagan County, Texas & 12 & 1 & & \\
\hline Upton County, Texas & 14 & 3 & $0.275(0.148)$ & $0.0011(0.0006)$ \\
\hline Val Verde County, Texas & 1 & 1 & & \\
\hline
\end{tabular}

Haplotype A, the most common haplotype, occurred in all subspecies' ranges (Fig. 3) and in $32(84 \%)$ of 38 populations. Two haplotypes occurred in C. s. squamata and C. s. hargravei, neither of which was unique to the range of either subspecies (Fig. 3). In contrast, 11 haplotypes occurred in C. s. pallida, of which 6 were unique, and 5 haplotypes were unique to C. s. castanogastris. Eight haplotypes (C, E, I, J, L, M, N, P) were "private haplotypes," with each restricted to a single population. The greatest diversity of haplotypes occurred within the range of C. s. castanogastris (Fig. 3, Table 3).

Fewer haplotypes $(h=7)$ occurred in the historical samples than in the recent samples $(h=13)$. Four haplotypes $(\mathrm{C}, \mathrm{E}, \mathrm{J}$, and P) were unique to the historical samples, whereas $8(\mathrm{~B}$, $\mathrm{H}, \mathrm{I}, \mathrm{K}, \mathrm{L}, \mathrm{M}, \mathrm{N}$, and $\mathrm{O}$ ) were unique to recent samples. The historical samples exhibited 


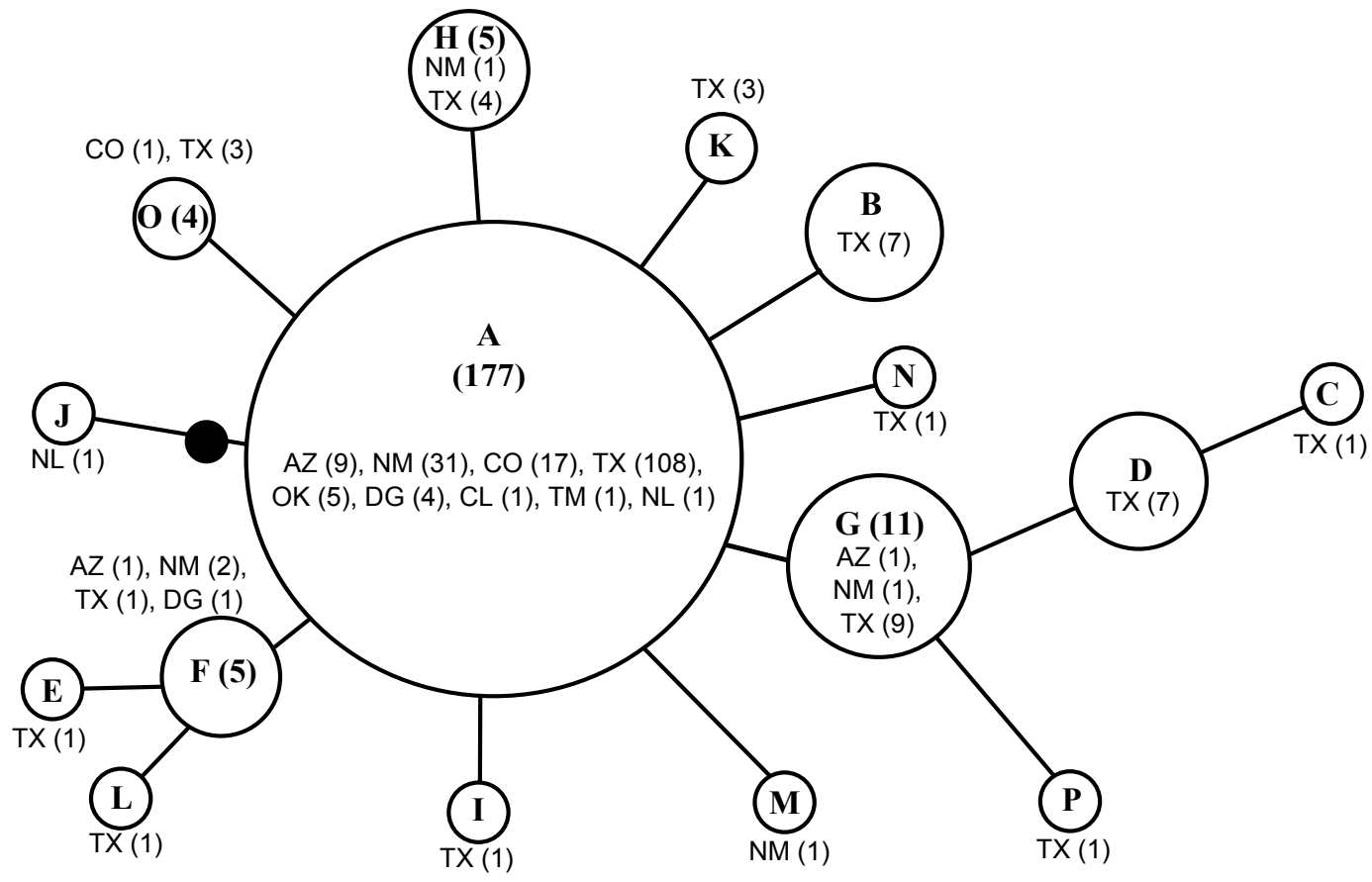

Fig. 2. Minimum spanning tree of 227 Scaled Quail (Callipepla squamata) mitochondrial control region haplotypes (267 bp). Each white circle represents a unique haplotype, with circle size proportional to each haplotype's overall frequency. Boldface letters (A, B, C, etc.) designate individual haplotypes, with the number of individuals (if $n>1$ ) possessing that haplotype in parentheses after the letter. Additional text inside or next to each haplotype represents the states of Mexico and the United States in which each haplotype occurred, and numbers in parentheses represent the frequency of occurrence. The single solid black circle represents an inferred missing haplotype. State codes are as follows: $\mathrm{AZ}=$ Arizona, $\mathrm{CO}=$ Colorado, $\mathrm{NM}=$ New Mexico, $\mathrm{OK}=$ Oklahoma, $\mathrm{TX}=$ Texas, $\mathrm{CL}=$ Coahuila, $\mathrm{DG}=$ Durango, $\mathrm{NL}=$ Nuevo León, $\mathrm{TM}=$ Tamaulipas.

slightly higher levels of haplotype and nucleotide diversity $(H d=0.510$, SD $0.109 ; \pi=$ 0.003, SD 0.0008) than the recent samples (Hd $=0.369, \mathrm{SD} 0.044 ; \pi=0.002, \mathrm{SD} 0.0003$ ).

The AMOVA results demonstrated that most genetic variation occurred within populations (80\%-94\%) regardless of how populations were grouped (Table 4). Among-group variation was consistently low. In terms of among-group differences, the arrangement of C. s. castanogastris versus a group composed of C. s. pallida, C. s. squamata, and C. s. hargravei (hereafter referred to as the "western group") accounted for the greatest variation $(12 \%, P<0.001)$.

The observed mismatch distribution (Fig. 4) failed to reject the null hypothesis of constant population size, as the observed and expected distributions were nearly identical. The mean absolute error, however, was relatively large (MAE $=0.128$ ), as was raggedness, but $r$ was statistically insignificant $(r=$
$0.154, P>0.05)$. Preliminary analysis showed that the observed mismatch distribution was also concordant with the expected distributions under models of sudden population expansion (Schneider and Excoffier 1999) and populations of fluctuating size (i.e., undergoing growth or decline; Rogers and Harpending 1992). The null hypothesis of demographic equilibrium was rejected by all neutrality tests, as Tajima's $D(D=-1.845, P<0.001)$, Fu and Li's $D^{*}\left(D^{*}=-2.590, P<0.05\right)$ and $F^{*}\left(F^{*}=\right.$ $-2.773, P=0.05)$, and Fu's $F_{S}\left(F_{S}=-16.838\right.$, $P<0.001)$ were negative and statistically different from 0 .

\section{Discussion}

Many nonavian vertebrates of southwestern North America possess highly divergent lineages that predate the Last Glacial Maximum (26,500-19,000 years ago). These taxa often display strong phylogeographic structure 

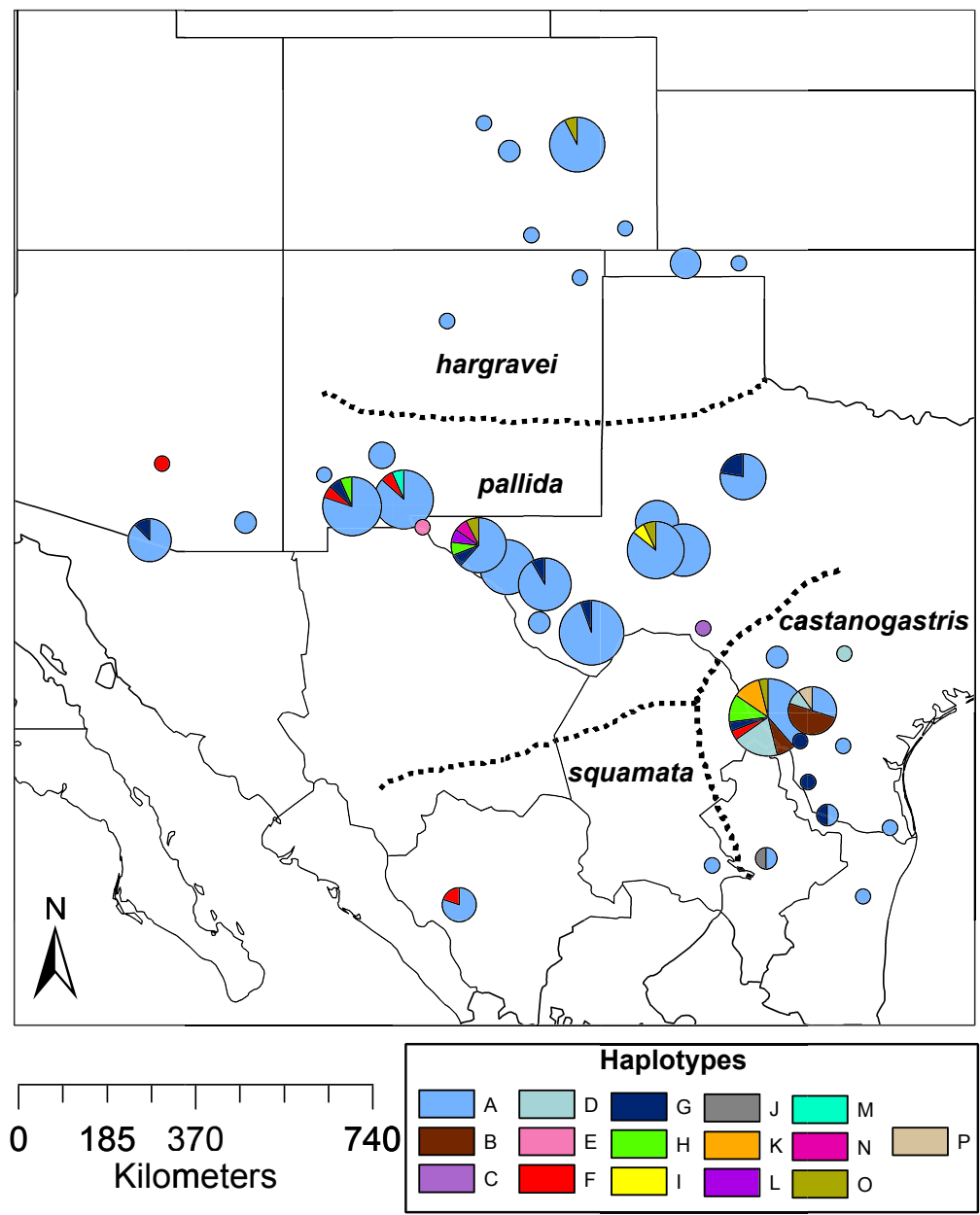

Fig. 3. Geographic distribution of 16 Scaled Quail (Callipepla squamata) control region haplotypes among 4 subspecies, 227 individuals, and 38 localities. Pie chart size reflects sample size, and slice size reflects the frequency of the corresponding haplotype.

associated with multiple Pleistocene refugia or ecogeographic barriers (Riddle and Hafner 2006, Pyron and Burbrink 2010). Scaled Quail are ground-dwelling birds and have a life history similar to rodents (i.e., largely sedentary, high reproductive rates, high mortality). Most species of small mammals in the North American arid regions exhibit deep divergence, a high degree of population structure, and deep phylogeographic breaks (Riddle et al. 2000, Neiswenter and Riddle 2010, 2011, Anderson and Light 2012). In contrast, we observed a lack of phylogeographic structure in the range of the Scaled Quail and found no empirical evidence of long-term historical isolation of populations in separate refugia. One explanation may be that the Scaled Quail has colonized much of its current range relatively recently, coincident with the expansion of grasslands (Axelrod 1985, Hoyt 2000) and desert thornscrub (Metcalfe 2006, Graham 2011) at the end of the Last Glacial Maximum. The Scaled Quail's distribution also has probably waxed and waned as grasslands and thorn-scrub habitats expanded and contracted due to Holocene climate fluctuations. Finally, the Scaled Quail may never have crossed any geographical barriers that would have reduced gene flow, or if such an event did occur, the populations did not persist.

Star-like haplotype networks or star phylogenies are characterized by an ancestral, common 


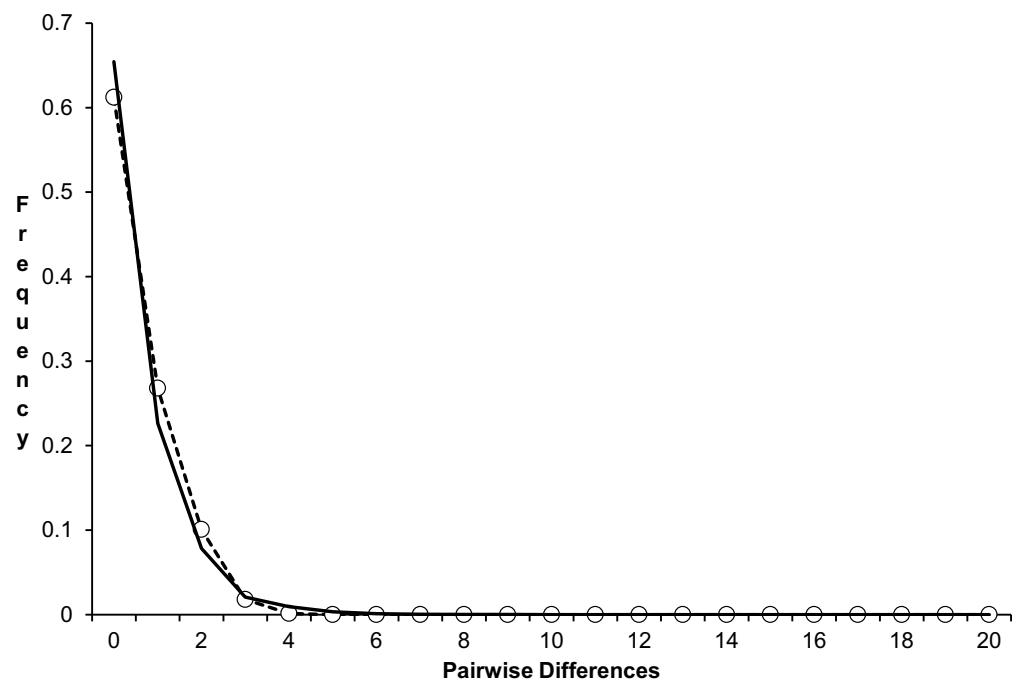

Fig. 4. Observed (dashed line) and expected (solid line) mismatch distributions based on 227 Scaled Quail (Callipepla squamata) control region sequences (267 bp). The $x$-axis is the number of pairwise differences (mismatches) and the $y$ axis represents the frequency of differences.

TABLE 4. Analysis of molecular variance results for sampled Scaled Quail (Callipepla squamata) based on different groupings of populations. Shown are the source of variation, degrees of freedom (df), sum of squares (SS), variance of components $(\varphi)$, percentage of variance $(\%)$, fixation index $(\Phi)$, and $P$ value indicating the significance $(95 \%$ confidence intervals) of the covariance of $\varphi$ and $\Phi$.

\begin{tabular}{|c|c|c|c|c|c|c|}
\hline Source of variation & df & SS & $\varphi$ & $\%$ & $\Phi$ & $P$ \\
\hline \multicolumn{7}{|l|}{ Populations grouped as 4 subspecies } \\
\hline Among groups & 3 & 3.421 & 0.016 & 5.99 & $\Phi_{\mathrm{CT}}=0.060$ & 0.0061 \\
\hline Among populations within groups & 36 & 13.338 & 0.027 & 10.00 & $\Phi_{\mathrm{SC}}=0.106$ & 0.0259 \\
\hline Within populations & 187 & 42.958 & 0.230 & 84.01 & $\Phi_{\mathrm{ST}}=0.160$ & 0.0027 \\
\hline Total $1-1$ & 226 & 59.718 & 0.273 & & & \\
\hline \multicolumn{7}{|c|}{ Combined C. s. pallida-C. s. hargravei-C. s. squamata } \\
\hline Among groups & 1 & 3.176 & 0.033 & 11.57 & $\Phi_{\mathrm{CT}}=0.116$ & 0.0003 \\
\hline Among populations within groups & 38 & 13.584 & 0.024 & 8.51 & $\Phi_{\mathrm{SC}}=0.096$ & 0.0610 \\
\hline Within populations & 187 & 42.958 & 0.230 & 79.92 & $\Phi_{\mathrm{ST}}=0.201$ & 0.0032 \\
\hline Total & 226 & 59.718 & 0.287 & & & \\
\hline \multicolumn{7}{|c|}{ Combined C. s. pallida-C. s. squamata-C. s. castanogastris } \\
\hline Among groups & 1 & 0.412 & -0.003 & -1.10 & $\Phi_{\mathrm{CT}}=-0.011$ & 0.4223 \\
\hline Among populations within groups & 38 & 16.348 & 0.037 & 14.02 & $\Phi_{\mathrm{SC}}=0.139$ & 0.0006 \\
\hline Within populations & 187 & 42.958 & 0.230 & 87.08 & $\Phi_{\mathrm{ST}}=0.129$ & 0.0034 \\
\hline Total & 226 & 59.718 & 0.264 & & & \\
\hline \multicolumn{7}{|c|}{ Combined C. s. squamata-C. s. hargravei-C. s. castanogastris } \\
\hline Among groups & 1 & 1.258 & 0.006 & 2.13 & $\Phi_{\mathrm{CT}}=0.021$ & 0.0260 \\
\hline Among populations within groups & 38 & 15.501 & 0.034 & 12.50 & $\Phi_{\mathrm{SC}}=0.128$ & 0.0596 \\
\hline Within populations & 187 & 42.958 & 0.230 & 85.38 & $\Phi_{\mathrm{ST}}=0.146$ & 0.0023 \\
\hline Total & 226 & 59.718 & 0.269 & & & \\
\hline \multicolumn{7}{|c|}{ Combined C. s. pallida-C. s. hargravei-C. s. castanogastris } \\
\hline Among groups & 1 & 0.125 & -0.024 & -9.73 & $\Phi_{\mathrm{CT}}=-0.097$ & 0.7796 \\
\hline Among populations within groups & 38 & 16.635 & 0.038 & 15.46 & $\Phi_{\mathrm{SC}}=0.141$ & 0.0026 \\
\hline Within populations & 187 & 42.958 & 0.230 & 94.27 & $\Phi_{\mathrm{ST}}=0.057$ & 0.0031 \\
\hline Total & 226 & 59.718 & 0.244 & & & \\
\hline
\end{tabular}

haplotype at the center of the star, with descendant haplotypes connected to it by short branches (Slatkin and Hudson 1991). This type of phylogeographic pattern usually results from recent, rapid demographic expansion (Slatkin and Hudson 1991). The star phylogeny and 
shallow phylogeographic structure (as seen from AMOVA results) of the Scaled Quail are evidence for past demographic expansion from a compact refugium. This conclusion was supported by negative, statistically significant values of Tajima's $D$, Fu and Li's $D^{*}$ and $F^{*}$, and Fu's $F_{S}$. The mismatch analysis proved uninformative probably due to the overall low variability of the control region sequences. Significant values of all neutrality tests are evidence against background selection. Genetic hitchhiking can also produce negative values of Fu's $F_{S}$ and Tajima's $D$ (Fu 1997). Genetic hitchhiking occurs when haplotypes of a specific gene become widespread in a population due to that gene's coincidental association with another locus that is under selection (Maynard Smith and Haigh 1974). Significant negative values of $\mathrm{Fu}$ and $\mathrm{Li}$ 's $D^{*}$ and $F^{*}$ are evidence against genetic hitchhiking because these statistics are far less sensitive to genetic hitchhiking than Fu's $F_{S}$ (Fu 1997). Therefore, we concluded that expansion from a single refugium, perhaps during the late Pleistocene or Holocene, best explained the phylogeographic structure of the Scaled Quail.

Late Quaternary glacial cycles and geographic barriers have had different effects on the vertebrate taxa of southwestern North America, where some species exhibit evidence of recent expansion from a single refugium (Zink et al. 2001, Zink 2002, Douglas et al. 2006, Riddle and Hafner 2006). The Scaled Quail is considered an aridland specialist (Silvy et al. 2007, Dabbert et al. 2009); therefore, its historical distribution has probably fluctuated repeatedly as periodic climatic changes resulted in expansion or contraction of preferred habitats. The climate of southwestern North America during the Last Glacial Maximum may have been as much as $5{ }^{\circ} \mathrm{C}$ cooler than today, with greater winter precipitation (Menking et al. 2004, Asmerom et al. 2010). Pollen and plant remains from woodrat (Neotoma spp.) middens indicate that woodlands of pine (Pinus spp.), juniper (Juniperus spp.), and oak (Quercus spp.) were widespread at lower elevations of the Chihuahuan Desert at this time (Wells 1966, Van Devender and Spaulding 1979, Metcalfe et al. 2002, Holmgren et al. 2007). Scaled Quail often occur in habitats with a high percentage of bare ground, and they tend to avoid areas of dense shrublands and grasslands (Schemnitz 1964, Wilson and
Crawford 1987, Saiwana et al. 1998, Joseph et al. 2003). This type of habitat may not have been widely distributed in southwestern North America until the onset of warmer, drier conditions in the region 15,000 years ago (Metcalfe et al. 2002, Holmgren et al. 2006, Pigati et al. 2009).

The distribution of haplotypes can provide qualitative insights into the location of Pleistocene refugia (Waltari et al 2007, Provan and Bennett 2008, Wilson and Pitts 2012). The highest haplotype and nucleotide diversity occurred within the range of castanogastris, which encompasses most of the Tamaulipan Brushlands. This high diversity may indicate that the Scaled Quail was isolated in this region during part of the Pleistocene and that the rest of the Scaled Quail range resulted from recent colonization. Lower genetic diversity is expected at the periphery of the expansion due to the loss of haplotypes through a series of founder events and local bottlenecks (Austerlitz et al. 1997). Little is known about the Pleistocene environments of southern Texas due to poor preservation of Quaternary pollen and plant macrofossils (Bryant and Holloway 1985) and limited attempts at recovery of such data (Presley 2003). Modern plant communities were present in southern Texas by the Late Holocene ( $\sim 6000$ years ago), but similar vegetation may have been present in southern Texas as early as the Late Pleistocene (Bryant and Holloway 1985).

Most of the phylogeographic signal in the data is probably the result of demographic events over many thousands of years. However, Scaled Quail have undergone additional range contractions and population declines during the past 40 years (Church et al. 1993). Population declines have been attributed to the combined effects of overgrazing, invasion of exotic grasses, and brush encroachment (Rollins 2000, Engel-Wilson and Kuvlesky 2002, Brennan and Kuvlesky 2005). Nonetheless, recent declines do not seem to have greatly affected the mtDNA diversity of the Scaled Quail. Historical (1880-1951) and contemporary (1977-2011) groups share many of the same haplotypes, and the contemporary group possesses more unique haplotypes than the historical group. The greater number of unique haplotypes in the contemporary group was probably due to the group's larger sample size. The higher haplotype and nucleotide 
diversity observed in the historical group was due to the group's higher relative frequencies of the haplotypes.

Genetic diversity in Scaled Quail was exceptionally low in comparison with its close relatives, Northern Bobwhite and Gambel's Quail. Eo et al. (2010) found 41 control region haplotypes and high levels of haplotype $(H d=$ $0.89)$ and nucleotide diversity $(\pi=0.0034)$ among bobwhites in the southeastern United States. A more geographically restricted study of Northern Bobwhites in southern Texas also showed higher levels of genetic diversity $(h=$ $42, H d=0.88, \pi=0.008$; Wehland 2006). A rangewide study of the Gambel's Quail revealed a greater number of haplotypes $(n=$ 36) and higher haplotype $(H d=0.79)$ and nucleotide diversity ( $\pi=0.009$; Williford 2013). The low genetic diversity observed in the Scaled Quail may be due to either a lower long-term effective population size or insufficient geographic sampling in the Mexican portion of the Scaled Quail's range. Additional specimens from Mexico are needed to determine whether low genetic diversity is a characteristic of the Scaled Quail throughout its range.

Translocations and interbreeding among different populations represent a potential pitfall of phylogeographic studies of game species such as the Scaled Quail. Managers have repeatedly attempted to bolster local populations of Scaled Quail with translocated stock; however, most introductions of Scaled Quail within and outside of the species range have failed (Casto 2006, Dabbert et al. 2009). Infrequent occurrence of specimens of Scaled Quail with chestnut bellies in Arizona outside of the range of C. s. castanogastris has led some authorities to suggest that at least a few introductions have been successful (Brown 1989). If reproductively and ecologically compatible, translocated stock can increase local and regional genetic diversity (Ciborowski et al. 2007, Johnson et al. 2010, Herber et al. 2012). But translocations may also reduce diversity due to strong introgression of genes from introduced populations into native ones, founder effects and subsequent inbreeding depression in isolated populations, or outbreeding depression due to hybridization of ecologically incompatible stocks (Rhymer and Simberloff 1996, Avise 2004, Edmands 2007). The overall low levels of haplotype and nucleotide diversity observed in the Scaled Quail could be viewed as evidence that successful translocations may have reduced genetic diversity in some parts of the species' range. Although Late Quaternary expansion is overall a more satisfactory explanation, we cannot exclude the possibility that translocation and restocking have also impacted the Scaled Quail's phylogeographic structure.

The lack of congruence between patterns of mtDNA variation and taxonomic designations of Scaled Quail subspecies brings into question the validity of retaining these currently recognized taxa. Incongruence between mtDNA variation and subspecies designations in birds is probably because many subspecies described in the early 20th century were based on one or a few arbitrarily chosen characters (Zink 2004). However, conflicts between subspecies taxonomy and mtDNA phylogeography may be the result of faulty delineation of subspecies boundaries, as most subspecies and populations have not been critically examined (Remsen 2010, Winker 2010). The largest study of geographic variation of plumage coloration and morphology within the Scaled Quail focused on the northwestern portion of the range (Rea 1973). Furthermore, discordance among mtDNA phylogeography and subspecies taxonomy is sometimes due to the different rates of evolution among mtDNA and nuclear genes that control phenotypic traits (Edwards et al. 2005, Mumme et al. 2006, Pérez-Emán et al. 2010). Many of the morphological traits may be of relatively recent origin; therefore, neutral markers may not reflect the divergence of and variation in adaptive loci of phenotypically diagnosable subspecies (Remsen 2010). A single gene will rarely capture the full evolutionary history of a species (Remsen 2010).

Analysis of molecular variance showed that approximately $12 \%$ of the genetic variation in the Scaled Quail was due to the differentiation between the western subspecies and C. s. castanogastris. The castanogastris subspecies is easily distinguished from the other subspecies by the chestnut patch on the belly, a discrete trait that might have a genetic basis. Historically, the geographic ranges of pallida and castanogastris were known to overlap in the Texas counties of Kinney, Uvalde, Real, and Bandera (Texas Game, Fish and Oyster Commission 1945). Anecdotal observations suggest 
that C. $s$. castanogastris may be ecologically segregated from C. s. pallida, because pallida is most abundant in open grasslands with little $(10 \%-15 \%)$ shrub cover, while castanogastris uses thorn-scrub vegetation (Silvy et al. 2007). If pallida and castanogastris are adapted to different habitats, then gene flow may be reduced or absent between these 2 subspecies. Comparative ecological studies have not been conducted in Kinney County, where these 2 subspecies may still coexist.

A rangewide study of geographic variation of phenotypic traits is needed to determine the diagnosability of the 4 subspecies of the Scaled Quail. Microsatellite data combined with comparative natural history studies could help to determine the level of ecological and genetic differentiation between C. s. castanogastris and western subspecies of the Scaled Quail. Additional sampling of the Mexican portion of the range would also help to further refine the phylogeographic and demographic history of the Scaled Quail.

\section{ACKNOWLEDGMENTS}

We thank the American Museum of Natural History, the Texas Cooperative Wildlife Collection, and the University of Colorado $\mathrm{Mu}$ seum of Natural History for use of their collections. We also thank D. Rollins and the Rolling Plains Quail Research Ranch, Faith Ranch, D. Schoeling and R. Kemph of the Oklahoma Department of Wildlife Conservation, E. Grahman, Hixon Ranch, L. Harveson, and S.D. Schmenitz for assistance in providing hunterharvested Scaled Quail wings. We also extend thanks to K. Miller, D. Hewitt, B. Ballard, and 2 anonymous reviewers for reviews of this manuscript. Funding for this research was provided by the Elliot B. and Adelle Bottom Fellowship in Quail Research and the South Texas Quail Associates. Laboratory facilities were enhanced by gifts from the Lawrence Family Foundation and the Caesar Kleberg Foundation. The C.C. Winn Endowed Chair supported L.A. Brennan, and the Alfred C. Glassell, Jr., Endowed Professorship supported F. Hernández. This is Caesar Kleberg Wildlife Research Institute Publication Number 13-114.

\section{Literature Cited}

Anderson, J.J., And J.E. Light. 2012. Phylogeography and subspecies revision of the hispid pocket mouse,
Chaetodipus hispidus (Rodentia: Heteromyidae). Journal of Mammalogy 93:1195-1215.

Asmerom, Y., V.J. Polyak, and S.J. Burns. 2010. Variable winter moisture in the southwestern United States linked to rapid glacial climate shifts. Nature Geoscience 3:114-117.

Austerlitz, F., B. Jung-Miller, B. Godelle, and P.-H. GouYON. 1997. Evolution of coalescence times, genetic diversity and structure during colonization. Theoretical Population Biology 51:148-165.

AVISE, J.C. 2004. Molecular markers, natural history, and evolution. 2nd edition. Sinauer Associates, Inc., Sunderland, MA.

AxeLrod, D.I. 1985. Rise of the grassland biome, central North America. Botanical Review 51:163-201.

Brennan, L.A., AND W.P. KuvLesky JR. 2005. North American grassland birds: an unfolding conservation crisis? Journal of Wildlife Management 69:1-13.

Brown, D.E. 1989. Arizona game birds. University of Arizona Press, Tucson, AZ.

Bryant, V.M., Jr., and R.G. Holloway. 1985. A LateQuaternary paleoenvironmental record of Texas: an overview of the pollen evidence. Pages 39-70 in V.M. Bryant Jr. and R.G. Holloway, editors, Pollen records of Late-Quaternary North American sediments. American Association of Stratigraphic Palynologists Foundation, Dallas, TX.

Casto, S.D. 2006. Early attempts to raise and stock game birds in Texas. Bulletin of the Texas Ornithological Society 39:17-22.

Church, K.E., J.R. Sauer, and S. Droege. 1993. Population trends of quails in North America. Proceedings of the National Quail Symposium 3:44-54.

Ciborowski, K.L., S. Consuegra, C. García de Leániz, J. Wang, M.A. Beaumont, and W.C. Jordan. 2007. Stocking may increase mitochondrial DNA diversity but fails to halt the decline of endangered Atlantic salmon populations. Conservation Genetics 8:1355-1367.

Dabbert, C.B., G. Pleasant, and S.D. Schemnitz. 2009. Scaled Quail (Callipepla squamata) [online]. In: A. Poole, editor, The Birds of North America Online. Cornell Lab of Ornithology, Ithaca, NY. Available from: http://bna.birds.cornell.edu/bna/species/106

Depaulis, F., S. Mousset, and M. Veuille. 2003. Power of neutrality tests to detect bottlenecks and hitchhiking. Journal of Molecular Evolution 57:S190-S200.

Douglas, M.E., M.R. Douglas, G.W. SchuetT, and L.W. PorRas. 2006. Evolution of rattlesnakes (Viperidae; Crotalus) in the warm deserts of western North America shaped by Neogene vicariance and Quaternary climate change. Molecular Ecology 15:3353-3374.

EDmands, S. 2007. Between a rock and a hard place: evaluating the relative risks of inbreeding and outbreeding for conservation and management. Molecular Ecology 16:463-475.

Edwards, S.V., S.B. Kingan, J.D. Calkins, C.N. BalakRISHnan, W.B. Jennings, W.J. Swanson, and M.D. SorEnSON. 2005. Speciation in birds: genes, geography, and sexual selection. Proceedings of the National Academy of Sciences of the United States of America 102:6550-6557.

ENGEL-Wilson, R., AND W.P. KUVLESKY JR. 2002. Arizona quail: species in jeopardy? Proceedings of the National Quail Symposium 5:1-7.

Eo, S.H., J.P. Wares, AND J.P. CarRolL. 2010. Subspecies and units for conservation and management of the 
Northern Bobwhite in the eastern United States. Conservation Genetics 11:867-875.

Excoffier, L., AND H.E.L. Lischer. 2010. Arlequin suite ver 3.5: a new series of programs to perform population genetics analyses under Linux and Windows. Molecular Ecology Resources 10:564-567.

Excoffier, L., P. Smouse, And J. Quattro. 1992. Analysis of molecular variance inferred from metric distances among DNA haplotypes: application to human mitochondrial DNA restriction data. Genetics 131:479-491.

FAY, J.C., AND C.-I. WU. 1999. A human population bottleneck can account for the discordance between patterns of mitochondrial versus nuclear DNA variation. Molecular Biology and Evolution 16:1003-1005.

FU, Y.-X. 1997. Statistical tests of neutrality of mutations against population growth, hitchhiking, and background selection. Genetics 147:915-925.

Fu, Y.-X., AND W.H. LI. 1993. Statistical tests of neutrality of mutations. Genetics 133:693-709.

Graham, A. 2011. A natural history of the New World: the ecology and evolution of plants. University of Chicago Press, Chicago, IL.

GutíERReZ, R.J., R.M. ZinK, and S.Y. Yang. 1983. Genic variation, systematic, and biogeographic relationships of some galliform birds. Auk 100:33-47.

Harpending, H.C. 1994. Signature of ancient population growth in a low-resolution mitochondrial mismatch distribution. Human Biology 66:591-600.

Herber, S., J.V. Briskie, and L.A. Apiolaza. 2012. A test of the 'genetic rescue' technique using donor populations of Drosophila melanogaster. PLOS ONE 7: e43113.

Holman, J.A. 1961. Osteology of living and fossil New World quails (Aves, Galliformes). Bulletin of the Florida State Museum, Biological Sciences 6:131-233.

Holmgren, C.A., J.L. Betancourt, and K.A. Rylander. 2006. A 36,000-yr vegetation history from the Pelocillo Mountains, southeastern Arizona, USA. Palaeogeography, Palaeoclimatology, Palaeoecology 240: 405-422.

Holmgren, C.A., J. Norris, And J.L. Betancourt. 2007. Inferences about winter temperatures and summer rains from the late Quaternary record of $\mathrm{C}_{4}$ perennial grasses and $\mathrm{C}_{3}$ desert shrubs in the northern Chihuahuan Desert. Journal of Quaternary Science 22:141-161.

Hoyt, C.A. 2000. Pollen signatures of the arid to humid grasslands of North America. Journal of Biogeography 27:687-696.

HubBaRd, J.P. 1973. Avian evolution in the aridlands of North America. Living Bird 12:155-196.

Hummel, S. 2003. Ancient DNA typing. Springer, Berlin, Germany.

Johnson, W.E., D.P. Onorato, M.E. Roelke, E.D. Land, M. Cunningham, R.C. Belden, R. McBride, D. Jansen, M. Lotz, D. Shindle, ET AL. 2010. Genetic restoration of the Florida panther. Science 329: 1641-1645.

Joseph, J., J.L. Holechek, R. Valdez, M. Collins, and M. Thomas. 2003. Effects of rangeland ecological condition on Scaled Quail sightings. Journal of Range Management 56:314-318.

Larkin, M.A., G. Blackshields, N.P. Brown, R. Chenna, P.A. McGettigan, H. McWilliam, F. Valentin, I.M. Wallace, A. Wilm, R. Lopez, et aL. 2007. Clustal W and Clustal X version 2.0. Bioinformatics 23:2947-2948.
Librado, P., AND J. Rozas. 2009. DnaSP v5: a software for comprehensive analysis of DNA polymorphism data. Bioinformatics 25:1451-1452.

Maynard Smith, J., AND J. Haigh. 1974. The hitch-hiking effect of a favourable gene. Genetical Research 23: $23-35$.

Mayr, E., AND L.L. Short. 1970. Species taxa of North American birds: a contribution to comparative systematics. Publications of the Nuttall Ornithological Club 9:1-127.

Menking, K.M., R.Y. Anderson, N.G. Shafike, K.H. Syed, AND B.D. Allen. 2004. Wetter or colder during the Last Glacial Maximum? Revisiting the pluvial lake question in southwestern North America. Quaternary Research 62:280-288.

Metcalfe, S., A. Say, S. Black, R. McCulloch, and S. O'Hara. 2002. Wet conditions during the last glaciation in the Chihuahuan Desert, Alta Babicora, and Mexico. Quaternary Research 57:91-101.

MetCalfe, S.E. 2006. Late Quaternary environments of the northern deserts and central Transvolcanic Belt of Mexico. Annals of the Missouri Botanical Garden 93:258-273.

Mulligan, C.J. 2005. Isolation and analysis of DNA from archaeological, clinical, and natural history specimens. Methods in Enzymology 395:87-103.

Mumme, R.L., M.L. Galatowitsch, P.G. Jabloński, T.M. STWARCZYK, AND J.P. CYGAN. 2006. Evolutionary significance of geographic variation in a plumage-based foraging adaptation: an experimental test in the Slate-throated Redstart (Myioborus minatus). Evolution 60:1086-1097.

MuNDY, N.I., P. UNITT, AND D.S. WoODRUFF. 1997. Skin from feet of museum specimens as a non-destructive source of DNA for avian genotyping. Auk 114:126-129.

Nedbal, M.A., R.L. Honeycutt, S.G. Evans, R.M. WhitING JR., AND D.R. DiETZ. 1997. Northern Bobwhite restocking in east Texas: a genetic assessment. Journal of Wildlife Management 61:854-863.

NEI, M. 1987. Molecular evolutionary genetics. Columbia University Press, New York, NY.

Neiswenter, S.A., And B.R. Riddle. 2010. Diversification of the Perognathus flavus species group in emerging arid grasslands of western North America. Journal of Mammalogy 91:348-362.

2011. Landscape and climatic effects on the evolutionary diversification of the Perognathus fasciatus species group. Journal of Mammalogy 92:982-993.

PäÄbo, S., H. Poinar, D. Serre, V. Jaenicke-Després, J. Hebler, N. Rohland, M. Kuch, J. Krause, L. VigiLANT, AND M. Hofreiter. 2004. Genetic analyses from ancient DNA. Annual Reviews in Genetics 38:645-679.

Pérez-Emán, J.L., R.L. Mumme, and P.G. Jabloński. 2010. Phylogeography and adaptive plumage evolution in Central American subspecies of the Slatethroated Redstart (Myioborus miniatus). Ornithological Monographs 67:90-102.

Pigati, J.S., J.E. Bright, T.M. Shanahan, and S.A. MaHAN. 2009. Late Pleistocene paleohydrology near the boundary of the Sonoran and Chihuahuan deserts, southeastern Arizona, USA. Quaternary Science Reviews 28:286-300.

Presley, A.L. 2003. Antiquity and paleoenvironment of the Tamaulipan Biotic Province of southern Texas: the zooarchaeological perspective. Master's thesis, Texas A\&M University, College Station, TX. 
Provan, J., and K.D. Bennett. 2008. Phylogeographic insights into cryptic glacial refugia. Trends in Ecology and Evolution 23:564-571.

Pyron, R.A., And F.T. Burbrink. 2010. Hard and soft allopatry: physically and ecologically mediated modes of geographic speciation. Journal of Biogeography 37:2005-2015.

Ramírez-Soriano, A., S.E. Ramos-Onsins, J. Rozas, F. CALAfEll, AND A. NAVARro. 2008. Statistical power analysis of neutrality tests under demographic expansions, contractions and bottlenecks with recombination. Genetics 179:555-567.

REA, A.M. 1973. The Scaled Quail (Callipepla squamata) of the Southwest: systematic and historical consideration. Condor 75:322-329.

Remsen, J.V., JR. 2010. Subspecies as a meaningful taxonomic rank in avian classification. Ornithological Monographs 67:62-78.

Rhymer, J.M., and D. Simberloff. 1996. Extinction by hybridization and introgression. Annual Review of Ecology and Systematics 27:83-109.

Riddle, B.R., AND D.J. Hafner. 2006. A step-wise approach to integrating phylogeographic and phylogenetic biogeographic perspective on the history of a core North American warm desert biota. Journal of Arid Environments 66:435-461.

Riddle, B.R., D.J. Hafner, and L.F. Alexander. 2000. Phylogeography and systematics of the Peromyscus eremicus species group and the historical biogeography of North American warm regional deserts. Molecular Phylogenetics and Evolution 17: $145-160$.

Ridgely, R.S., T.F. Allnutt, T. Brooks, D.K. McNicol, D.W. Mehlman, B.E. YounG, AND J.R. ZoOK. 2007. Digital distribution maps of the birds of the western hemisphere, version 3.0. NatureServe, Arlington, VA. Available from: http://www.natureserve.org

Ridgway, R., AND H. Friedmann. 1946. The birds of North and Middle America. Smithsonian Institution United States National Museum, Bulletin 50, Volume 10. Smithsonian Institution, Washington, DC.

Rogers, A.R., A.E. Fraley, M.J. Bamshad, W. Scott WatKins, AND L.B. JoRDE. 1996. Mitochondrial mismatch analysis is insensitive to the mutational process. Molecular Biology and Evolution 13:895-902

Rogers, A.R., and H. Harpending. 1992. Population growth makes waves in the distribution of pairwise genetic differences. Molecular Biology and Evolution 9:552-569.

RoLLins, D. 2000. Status, ecology and management of Scaled Quail in west Texas. Proceedings of the National Quail Symposium 4:165-172.

Saiwana, L., J.L. Holechek, A. Tembo, R. Valdez, and M. Cardenas. 1998. Scaled Quail use of different seral stages in the Chihuahuan Desert. Journal of Wildlife Management 62:550-556.

Schneider, S., AND L. ExCoffier. 1999. Estimation of past demographic parameters from the distribution of pairwise differences when mutation rates vary among sites: application to human mitochondrial DNA. Genetics 152:1079-1089.

Schemnitz, S.D. 1959. Past and present distribution of Scaled Quail (Callipepla squamata) in Oklahoma. Southwestern Naturalist 4:148-152.

1964. Comparative ecology of bobwhite and Scaled Quail in the Oklahoma Panhandle. American Midland Naturalist 71:429-433.
Silvy, N.J., D. Rollins, and S.W. Whisenant. 2007. Scaled Quail ecology and life history. Pages 65-88 in L.A. Brennan, editor, Texas quails: ecology and management. Texas A\&M University Press, College Station, TX.

Simonsen, K.L., G.A. Churchill, and C.F. Aouadro. 1995. Properties of statistical tests of neutrality for DNA polymorphism. Genetics 141:413-429.

Slatkin, M., And R.R. Hudson. 1991. Pairwise comparisons of mitochondrial DNA sequences in stable and exponentially growing populations. Genetics 129:555-562.

TAJIMA, F. 1989. Statistical method for testing the neutral mutation hypothesis by DNA polymorphism. Genetics 123:585-595.

Teacher, A.G.F., AND D.J. Griffiths. 2011. HAPSTAR: automated haplotype network layout and visualization. Molecular Ecology Resources 11:151-153.

Texas Game, Fish and Oyster Commission. 1945. Principal game birds and mammals of Texas. Texas Game, Fish and Oyster Commission, Austin, TX.

Van Den Bussche, R.A., S.R. Hoofer, D.A. WiedenFELD, D.H. Wolfe, and S.D. Sherrod. 2003. Genetic variation within and among fragmented populations of Lesser Prairie-Chickens (Tympanuchus pallidicinctus). Molecular Ecology 12:675-683.

Van Devender, T.R., and W.G. Spaulding. 1979. Development of vegetation and climate in the southwestern United States. Science 204:701-710.

Vigilant, L., M. Stoneking, H.C. Harpending, K. Hawkes, AND A.C. WiLson. 1991. African populations and the evolution of human mitochondrial DNA. Science 253:1503-1507.

Waltari, E., R.J. Hijmans, A.T. Peterson, Á.S. Nyári, S.L. Perkins, and R.P. Guralnick. 2007. Locating Pleistocene refugia: comparing phylogeographic and ecological niche model predictions. PLOS ONE 2:e563.

Watterson, G.A. 1975. On the number of segregating sites in genetical models without recombination. Theoretical Population Biology 7:256-276.

WeHLAND, E.M. 2006. Genetic variation among south Texas populations of Northern Bobwhite. Master's thesis, Texas A\&M University-Kingsville, Kingsville, TX.

WELLS, P.V. 1966. Late Pleistocene vegetation and degree of pluvial climatic change in the Chihuahuan Desert. Science 153:970-975.

Wenink, P.W., A.J. Baker, and M.G. Tilanus. 1994. Mitochondrial control-region sequences in two shorebird species, the Turnstone and the Dunlin, and their utility in population genetic studies. Molecular Biology and Evolution 11:22-31.

WiLLiforD, D.L. 2013. Molecular genetics of Northern Bobwhite, Scaled Quail, and Gambel's Quail. Doctoral dissertation, Texas A\&M University-Kingsville, Kingsville, TX

Wilson, J.S., AND J.P. PitTs. 2012. Identifying Pleistocene refugia in North American cold deserts using phylogeographic analyses and ecological niche modeling. Diversity and Distributions 18:1139-1152.

WiLson, M.H., AND J.A. Crawford. 1987. Habitat selection by Texas bobwhites and Chestnut-bellied Scaled Quail in South Texas. Journal of Wildlife Management 51:575-582.

WinkeR, K. 2010. Subspecies represent geographically partitioned variation, a gold mine of evolutionary biology, and a challenge for conservation. Ornithological Monographs 67:6-23. 
ZINK, R.M. 2002. Methods in comparative phylogeography, and their application to studying evolution in the North American aridlands. Integrative Comparative Biology 42:953-959.

2004. The role of subspecies in obscuring avian biological diversity and misleading conservation policy. Proceedings of the Royal Society of London B, Biological Sciences 271:561-564.

ZinK, R.M., AND R.C. BLACKWELL. 1998. Molecular systematics of the Scaled Quail complex (genus Callipepla). Auk 115:394-403.
Zink, R.M., A.E. Kessen, T.V. Line, and R.C. BlackWELL-RAGO. 2001. Comparative phylogeography of some aridland bird species. Condor 103:1-10.

Received 14 August 2013 Accepted 11 October 2013 